\title{
Variation in the wood anatomical structure of Gmelina arborea (Verbenaceae) trees at different ecological conditions in Costa Rica
}

\author{
Róger Moya ${ }^{1} \&$ Mario Tomazello $\mathrm{Fo}^{2}$ \\ 1. Escuela de Ingeniería Forestal, Instituto Tecnológico de Costa Rica, Apartado 159-7050, Cartago, Costa Rica; \\ rmoya@itcr.ac.cr \\ 2. Departamento de Ciências Florestais, ESALQ/Universidade de São Paulo, Av. Pádua Dias, 11-Caixa Postal 09, CEP \\ 13418-900, Piracicaba, São Paulo, Brasil; mtomazel@esalq.usp.br
}

Received 01-XI-2006. Corrected 06-VII-2007. Accepted 23-X-2007.

\begin{abstract}
The tree Gmelina arborea has been widely introduced in Costa Rica for commercial purposes. This new conditions for melina cause variations on anatomy in secondary xylem of the trees growing in plantations. The objective of the present research was to determine the variation in the anatomy of xylem caused by the ecological conduction variation. Dimensions of fiber, axial parenchyma percentage of cross sections, parameters of vessels and the ray were measured. The results showed that some anatomical characteristics remained stable despite variations of ecological conditions, especially radial parenchyma and anatomical features which were less affected by the altitude. On the other hand, the vessels, axial parenchyma and fiber were less stable because they were affected significantly by the longitude, latitude, altitude and precipitation. Latitude significantly affected vessel percentage, length and diameter of the fiber and lumen. Longitude affected vessel percentage and fiber diameter. Altitude had a significant correlation with the amount of cells at ray height. Annual average precipitation affected vessel percentage and diameter, not only of the fiber, but also of the lumen. These results suggest that the new growth conditions of $G$. arborea trees in Costa Rica have produced an anatomic adaptation. Rev. Biol. Trop. 56 (2): 689-704. Epub 2008 June 30.
\end{abstract}

Key words: plantation wood, properties, secondary xylem, geographical position, precipitation.

Gmelina arborea (melina) was introduced into reforestation programs in countries such as Myanmar and Bangladesh on early twentieth century. By the end of this century, the species had been introduced in several areas of the American tropical countries, Africa, and Asia (Douay 1956, Kalish 1975, Hornick et al. 1984). Reforestation with this species is oriented to the production of raw material for sawlog, energy, and pulp production (Dvorak 2004). This artificial migration includes regions that vary from $100^{\circ} \mathrm{W}$ to $180^{\circ} \mathrm{E}$ latitude and from $23^{\circ} \mathrm{N}$ to $40^{\circ} \mathrm{S}$ longitude (Fig. 1). The introduced sites have different ecological conditions compared to its natural habitat in Asia, mainly the ones related to the geography and precipitation. In Central America, for example, melina has been grown in a different precipitation level, temperature and fertility sites (Alfaro and De Camino 2002). In Costa Rica, G. arborea is planted in a variety of sites and growth conditions for the production of raw material for sawlog (Alfaro 2000, Moya 2004).

The anatomical structure of secondary xylem is composed by different types of woody cells (vessel, fiber and radial and axial parenchyma), whose origins are in vascular cambium (Plomion et al. 2001). During their formation these cells are affected by many factors such as site, ecological conditions, management, genetics, and age for trees growing in plantation conditions (Zobel and Van Buijtenen 1989). The anatomical features are modified within trees during their growth in order to adjust 


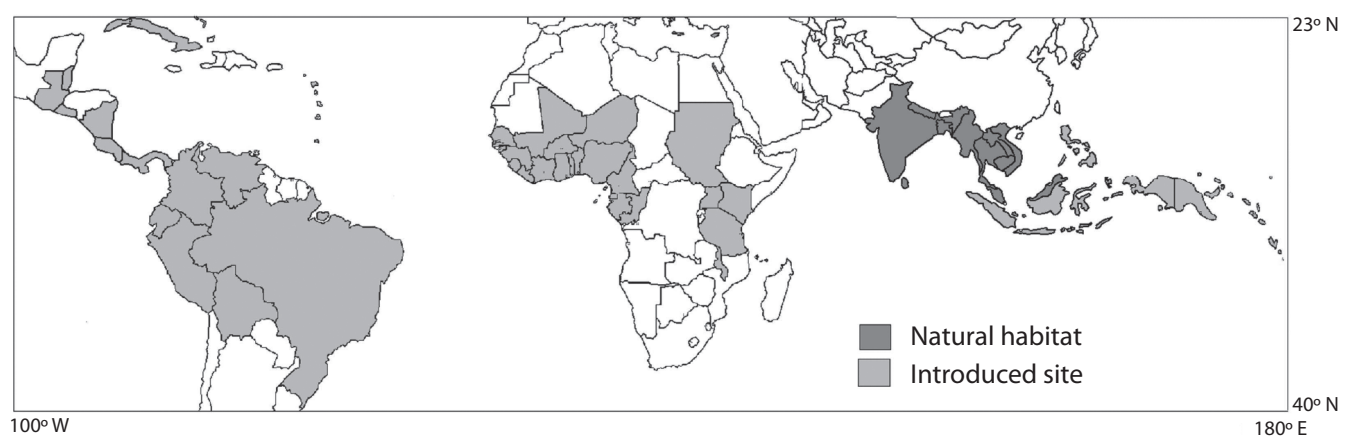

Fig. 1. Geographical range of Gmelina arborea around the world.

physiologic and water stress, then they maintain the existence of the species (Baas 1982, Metcalfe 1989).

For melina, many studies indicate that the variations in the anatomy of secondary xylem occurred in relation to tree age (Akachuku and Burley 1979, Akachuku 1985, Ohbayashi and Shiokura 1989, Nobuchi et al. 1997), growth conditions (Chowdhury 1947, 1953), growth rate (Esan 1966, Lamb 1968, Hughes and Esan 1969, Ohbayashi and Shiokura 1989, Nobuchi et al. 1997), differences in site fertility (Akachuku and Burley 1979, Ogbonnaya 1993), and water availability (Ogbonnaya et al. 1992). Based on a macroscopic examination of two Indian samples, Pearson and Brown (1932) have described in detail G. arborea wood. Other studies report the anatomical features variation. Chowdhury $(1947,1953)$ established three different porosities for different climatic conditions: diffuse, annular and semi-annular. The anatomical elements presented significant variation. Vessels percentage was negatively correlated with latitude, longitude, growth rate and tree height (Akachuku 1985, Akachuku and Burley 1979, Nobuchi et al. 1997). The length and diameter vessels increased to increment distance from the pith (Ohbayashi and Shiokura 1989, Nobuchi et al. 1997). Although vessels frequency decreased when pith distance or tree age increased (Frimpong-Mensah 1992, Nobuchi et al. 1997). Frimpong-Mensah (1992) found that cell wall thickness was significantly correlated with cambial age. Hughes and Esan (1969) found strong correlations between fiber length and tree age with distance from the pith in 9-year-old trees in Nigeria. Also in Nigeria, for 7 year-old trees, it was found that fiber length was different at four sites (Akachuku and Burley, 1979). In contrast, Frimpong-Mensah (1992) found no variation in fiber length with cambial age in 20 -year-old G. arborea trees in Ghana. Growth rate affects fiber dimensions too. Ohbayashi and Shiokura (1989) carried out a study on fiber length in 15-year-old trees and found that a high growth rate was strongly correlated with short fiber length.

The present research objective was to determine the differences in the anatomy of secondary xylem in melina trees growing in different geographic locations (latitude, longitude and altitude) and precipitation levels in the North and Northwest regions of Costa Rica.

\section{MATERIALS AND METHODS}

Sampled areas, silvicultural regimes, plots and tree selection: thirty mature trees from 30 different forest plantations stands, located in the North and Northwest regions of Costa Rica, were sampled in this study (Fig. 2). Both regions historically had been the most developed in Costa Rica in terms of reforestation, particularly with the species $G$. arborea. Regardless of this fact both regions 


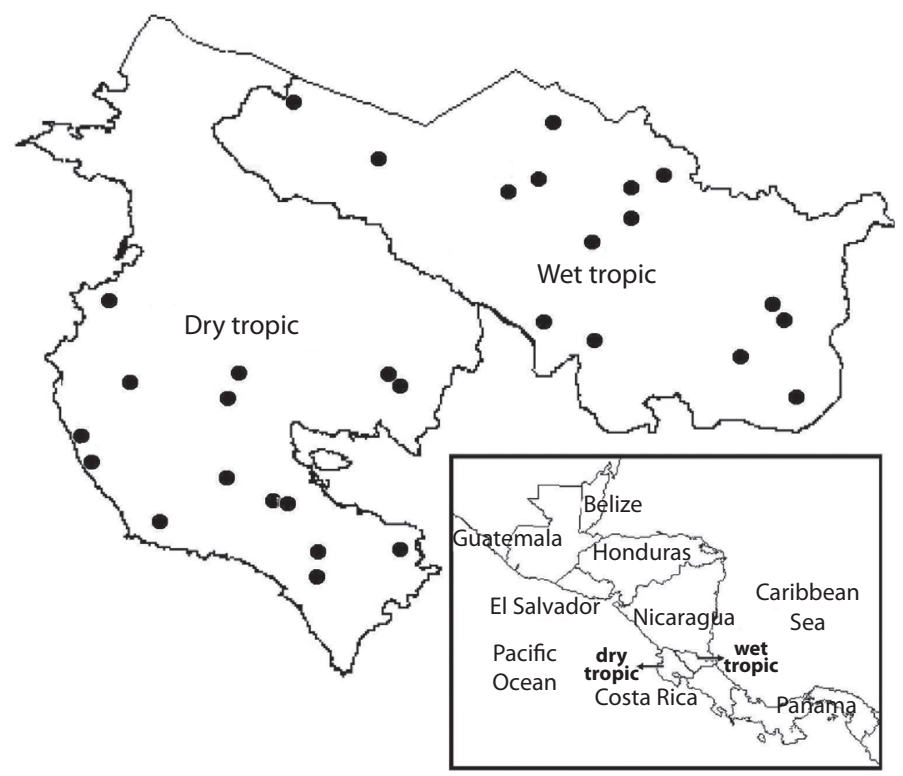

Fig. 2. Location of sampled plantations in the Northern and Northwestern regions of Costa Rica.

present contrasting climatic conditions, as it can be observed in Fig 3. The Northwest region has an annual average precipitation that ranges between 1500 to $2000 \mathrm{~mm}$, average annual temperatures of 25 to $28{ }^{\circ} \mathrm{C}$ with a strong dry season between January to April with almost $0 \mathrm{~mm}$ of precipitation. This area is commonly known as dry tropical forest (Bolaños and Watson 1993). The Northern region, classified as wet tropical forest (Bolaños and Watson
1993), has an annual average precipitation of 2800 to $5000 \mathrm{~mm}$, average annual temperature of 20 to $25^{\circ} \mathrm{C}$ with a short dry season during the months of February to March.

From each region of Costa Rica or climatic condition, 15 melina trees were selected from 15 different plantations with different level of management (Table 2). Nine to 12 year-old plantations were sampled and measured. In all plantations it was determined their geographic

\section{A}

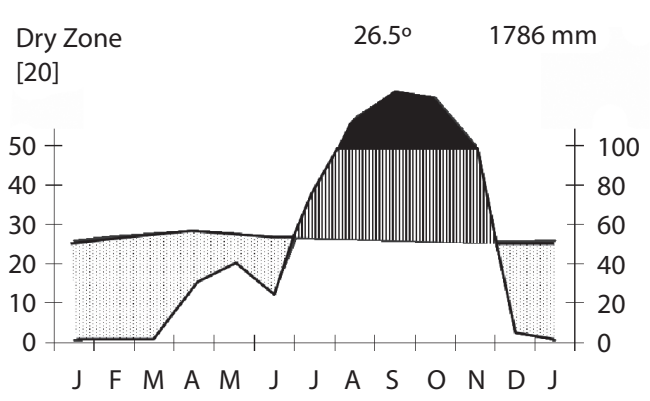

B

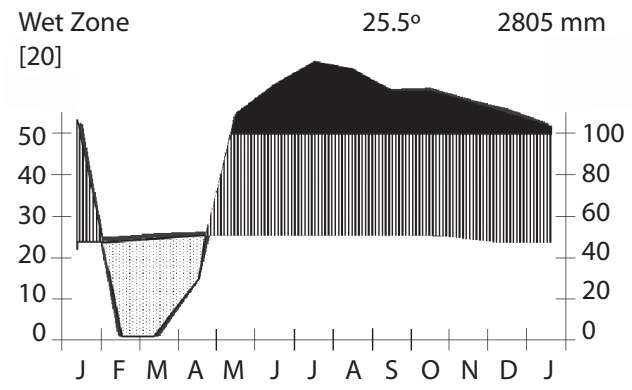

Fig. 3. Climadiagrams for the wet and dry study zones according to Walter and Lieth (1960). Note: to describe the climate for each study area we prepared climadiagrams using meteorological data with at least 20 years of monthly average temperature records and precipitation from San Jorge (Los Chiles) station, for wet tropical and from Hacienda Tempisque station for dry tropical. 
location by global position system (GPS), average diameter breast height (DBH), average tree total height (TTH), age and plantation density (PD). One healthy tree representing average diameter breast height (DBH), straight trunk and normal branching was selected for each trial, hence 30 sampled trees from 30 different plantations were analyzed in this research (Table 1, Fig. 2).

Wood samples: from each sampled tree, a stem disc (3 cm thick) was cut at DBH. Cross section with $1.0 \mathrm{~cm}$ in wide and $2.0 \mathrm{~cm}$ in length was obtained in central stem. Afterwards, cross section was separated in two samples in the pith localization (Fig. 4). These samples were conditioned at $22{ }^{\circ} \mathrm{C}$ and $60 \%$ relative humidity (wood sample reached $12 \%$ of moisture content). Wood density was determined in this condition. Annual rings boundaries, sap-heartwood demarcation and wood color by Munsell chats (Mac Corporation 1994). The macroscopic wood description was observed too. In north part of middle cross section were cut two samples in middle length. The upper part was used to obtain fiber dimensions and the lower part for thin wood sections (Fig. 4). Each distinct growth ring observed by the thickening of the cell wall fiber of superior part was separated and on the beginning part (like earlywood in temperate species) one sample was cut and macerated one sample using Franklin's method (Ruzin 1999). We decided to use only the beginning part of the annual ring -which is similar to earlywood in temperate species- given that the profile patterns of fiber dimensions are more or less stable from the beginning of the ring to 50\% (Moya \& Tomazzello 2007). Thin sections were cut at $0,25,50,75$ and $100 \%$ of distance between pith and bark (Fig. 4). Thin transversal sections, radial and tangential sections (permanent slides) about 10-15 $\mu \mathrm{m}$ thick from the inferior part were cut by using a microtome (Leica SM2000R). These sections were stained with congo-red and iodine-green, and prepared as semi-permanent slides using gelatin glycerin (Ruzin 1999).

In each sampled tree, thin transversal, radial and tangential sections at $75 \%$ of distance between pith and bark were observed on microscope for qualitative anatomical determinations, such as parenchyma presence and distribution, ray type and porosity. For quantitative parameters different methods were used. Three replica of each annual ring macerated and stained with safrani were madder to measure fiber dimensions (Table 2). The parameters of vessels and axial and ray parenchyma were measured in the transversal and tangential sections (Table 2). A digital camera on an optical microscope was used to photograph anatomical features. Twenty five different elements were measured for each anatomical feature. A magnification 250X for LF, VF, MVP, RF, RP, APP, RH and CRH, 1000X for FW and LD and 500X for VD, RW and CRH were used. Nomenclature and cell sizes were determined

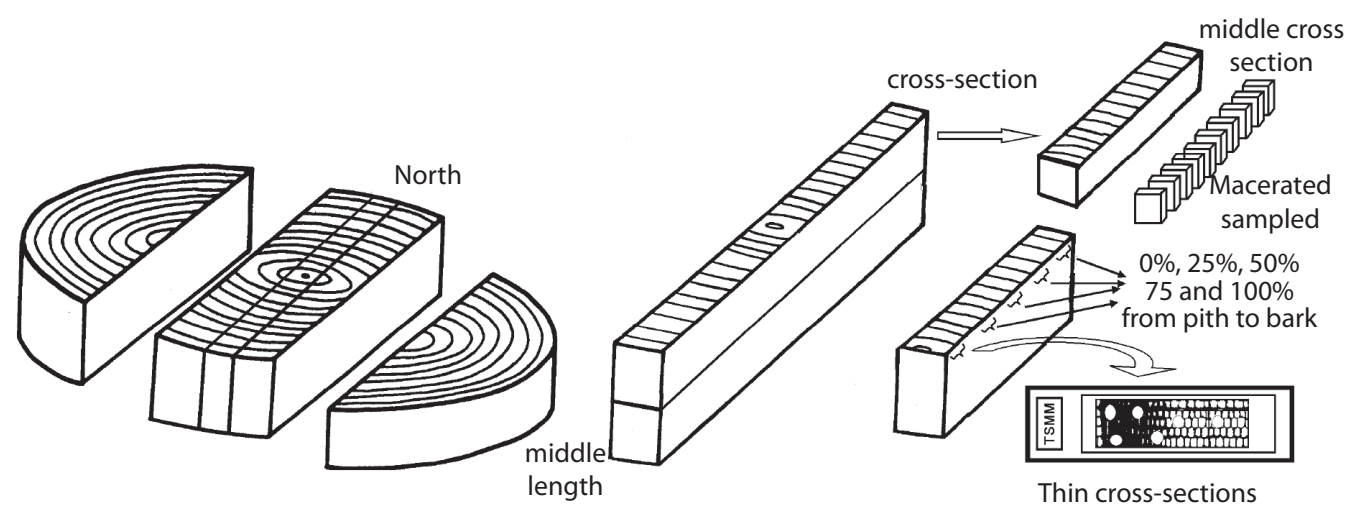

Fig. 4. Thin sections and macerated sampled from a stem section of Gmelina arborea trees. 
TABLE 1

Description of plantation samples and growing conditions

\begin{tabular}{|c|c|c|c|c|c|c|c|c|c|}
\hline $\begin{array}{l}\text { Climatic conditions } \\
\text { (region of } \\
\text { Costa Rica) }\end{array}$ & $\begin{array}{c}\text { Tree } \\
\text { number }\end{array}$ & $\begin{array}{l}\text { Latitude } \\
\left({ }^{\circ} \mathrm{N}\right)\end{array}$ & $\begin{array}{c}\text { Longitude } \\
\left({ }^{\circ} \mathrm{W}\right)\end{array}$ & $\begin{array}{l}\text { Density of } \\
\text { plantation } \\
\left(\mathrm{nha}^{-1}\right)\end{array}$ & $\begin{array}{l}\text { Altitude } \\
\text { (m) }\end{array}$ & $\begin{array}{c}\text { Mean } \\
\text { precipitation } \\
(\mathrm{mm})^{*}\end{array}$ & $\begin{array}{l}\text { Diameter at } \\
\text { breast height } \\
(\mathrm{cm})\end{array}$ & $\begin{array}{l}\text { Tree total } \\
\text { height } \\
\text { (m) }\end{array}$ & $\begin{array}{c}\text { Age } \\
\text { (years) }\end{array}$ \\
\hline \multirow{15}{*}{$\begin{array}{l}\text { Wet } \\
\text { (Northern) }\end{array}$} & W1 & $10^{\circ} 29^{\prime} 33^{\prime \prime}$ & $84^{\circ} 00^{\prime} 59^{\prime \prime}$ & 159 & 54 & 5683 & 38.0 & 25.5 & 9 \\
\hline & W2 & $10^{\circ} 56^{\prime} 37^{\prime \prime}$ & $84^{\circ} 37^{\prime} 23^{\prime \prime}$ & 300 & 47 & 3020 & 31.5 & 22.0 & 8 \\
\hline & W3 & $10^{\circ} 57^{\prime} 33^{\prime \prime}$ & $84^{\circ} 34^{\prime} 36^{\prime \prime}$ & 191 & 55 & 3089 & 33.2 & 18.5 & 10 \\
\hline & W4 & $10^{\circ} 46^{\prime} 44^{\prime \prime}$ & $84^{\circ} 41^{\prime} 24^{\prime \prime}$ & 223 & 100 & 3089 & 32.0 & 23.5 & 8 \\
\hline & W5 & $10^{\circ} 38^{\prime} 40^{\prime \prime}$ & $84^{\circ} 28^{\prime} 17^{\prime \prime}$ & 127 & - & 3089 & 30.7 & 18.0 & 9 \\
\hline & W6 & $10^{\circ} 15^{\prime} 17^{\prime \prime}$ & $83^{\circ} 57^{\prime} 51^{\prime \prime}$ & 659 & 320 & 3089 & 25.0 & 19.0 & 8 \\
\hline & W7 & $10^{\circ} 50^{\prime} 58^{\prime \prime}$ & $85^{\circ} 02^{\prime} 04^{\prime \prime}$ & 477 & 90 & 3020 & 28.5 & 22.5 & 8 \\
\hline & W8 & $10^{\circ} 57^{\prime} 57^{\prime \prime}$ & $84^{\circ} 37^{\prime} 08^{\prime \prime}$ & 350 & 94 & 2882 & 25.2 & 21.4 & 8 \\
\hline & W9 & $10^{\circ} 48^{\prime} 35^{\prime \prime}$ & $84^{\circ} 28^{\prime} 34^{\prime \prime}$ & 446 & 93 & 2882 & 30.0 & 23.2 & 8 \\
\hline & W10 & $10^{\circ} 26^{\prime} 42^{\prime \prime}$ & $84^{\circ} 37^{\prime} 23^{\prime \prime}$ & 505 & 250 & 3089 & 28.3 & 24.0 & 10 \\
\hline & W11 & $10^{\circ} 21^{\prime} 24^{\prime \prime}$ & $84^{\circ} 06^{\prime} 09^{\prime \prime}$ & 732 & 330 & 3089 & 24.0 & 21.8 & 9 \\
\hline & W12 & $11^{\circ} 00^{\prime} 04^{\prime \prime}$ & $85^{\circ} 14^{\prime} 25^{\prime \prime}$ & 1032 & 202 & 3020 & 21.5 & 21.5 & 8 \\
\hline & W13 & $10^{\circ} 50^{\prime} 02^{\prime \prime}$ & $84^{\circ} 42^{\prime} 33^{\prime \prime}$ & 764 & 22 & 2886 & 21.0 & 19.1 & 11 \\
\hline & W14 & $10^{\circ} 42^{\prime} 47^{\prime \prime}$ & $84^{\circ} 23^{\prime} 02^{\prime \prime}$ & 891 & 110 & 2886 & 24.1 & 15.0 & 10 \\
\hline & W15 & $10^{\circ} 23^{\prime} 47^{\prime \prime}$ & $84^{\circ} 28^{\prime} 30^{\prime \prime}$ & 1496 & 86 & 4903 & 24.3 & 20.0 & 12 \\
\hline \multirow{15}{*}{$\begin{array}{l}\text { Dry } \\
\text { (Northwest) }\end{array}$} & D1 & $10^{\circ} 18^{`} 11^{\prime \prime}$ & $84^{\circ} 58^{\prime} 47^{\prime \prime}$ & 318 & - & 1703 & 31.9 & 20.8 & 10 \\
\hline & D2 & $10^{\circ} 29^{\prime} 52^{\prime \prime}$ & $85^{\circ} 40^{\prime} 52^{\prime \prime}$ & 350 & 117 & 1781 & 29.8 & 19.5 & 11 \\
\hline & D3 & $10^{\circ} 10^{\prime} 06^{\prime \prime}$ & $84^{\circ} 47^{\prime} 06^{\prime \prime}$ & 223 & 38 & 1781 & 32.5 & 24.7 & 12 \\
\hline & D4 & $10^{\circ} 03^{\prime} 17^{\prime \prime}$ & $84^{\circ} 24^{\prime} 12^{\prime \prime}$ & 344 & 374 & 2567 & 30.5 & 24.0 & 10 \\
\hline & D5 & $09^{\circ} 52^{\prime} 23^{\prime \prime}$ & $85^{\circ} 10^{\prime} 05^{\prime \prime}$ & 250 & 98 & 2407 & 33.2 & 27.1 & 12 \\
\hline & D6 & $10^{\circ} 15^{\prime} 16^{\prime \prime}$ & $85^{\circ} 04^{\prime} 47^{\prime \prime}$ & 509 & 142 & 1737 & 19.7 & 19.5 & 11 \\
\hline & D7 & $10^{\circ} 30^{\prime} 19^{\prime \prime}$ & $85^{\circ} 43^{\prime} 23^{\prime \prime}$ & 477 & 92 & 1807 & 22.5 & 23.3 & 9 \\
\hline & D8 & $10^{\circ} 06^{\prime} 05^{\prime \prime}$ & $85^{\circ} 45^{\prime} 45^{\prime \prime}$ & 477 & 150 & 2564 & 23.4 & 17.8 & 10 \\
\hline & D9 & $09^{\circ} 59^{\prime} 37^{\prime \prime}$ & $85^{\circ} 17^{\prime} 38^{\prime \prime}$ & 605 & 484 & 2092 & 23.5 & 18.5 & 9 \\
\hline & D10 & $09^{\circ} 48^{`} 01^{\prime \prime}$ & $85^{\circ} 11^{\prime} 29^{\prime \prime}$ & 509 & 8 & 2407 & 23.9 & 22.1 & 8 \\
\hline & D11 & $10^{\circ} 18^{\prime} 52^{\prime \prime}$ & $85^{\circ} 02^{\prime} 18^{\prime \prime}$ & 827 & - & 1703 & 20.5 & 18.7 & 10 \\
\hline & D12 & $10^{\circ} 16^{\prime} 38^{\prime \prime}$ & $85^{\circ} 39^{\prime} 03^{\prime \prime}$ & 732 & 67 & 1737 & 18.8 & 19.0 & 9 \\
\hline & D13 & $10^{\circ} 14^{\prime} 58^{\prime \prime}$ & $85^{\circ} 39^{\prime} 31^{\prime \prime}$ & 836 & 112 & 1807 & 20.5 & 22.1 & 10 \\
\hline & D14 & $09^{\circ} 56^{\prime} 29^{\prime \prime}$ & $85^{\circ} 34^{\prime} 30^{\prime \prime}$ & 796 & 265 & 2092 & 20.7 & 18.3 & 10 \\
\hline & D15 & $09^{\circ} 52^{\prime} 11^{\prime \prime}$ & $84^{\circ} 57^{\prime} 38^{\prime \prime}$ & 1025 & - & 2407 & 20.2 & 22.0 & 9 \\
\hline
\end{tabular}

*Average annual precipitation used was based on the annual precipitation between 1990 and 2002. Source: Costa Rican Institute of Electricity (ICE) and National Service of Underground Waters, Irrigation and Draining (SENARA). 
TABLE 2

Anatomical features measured and abbreviations utilized

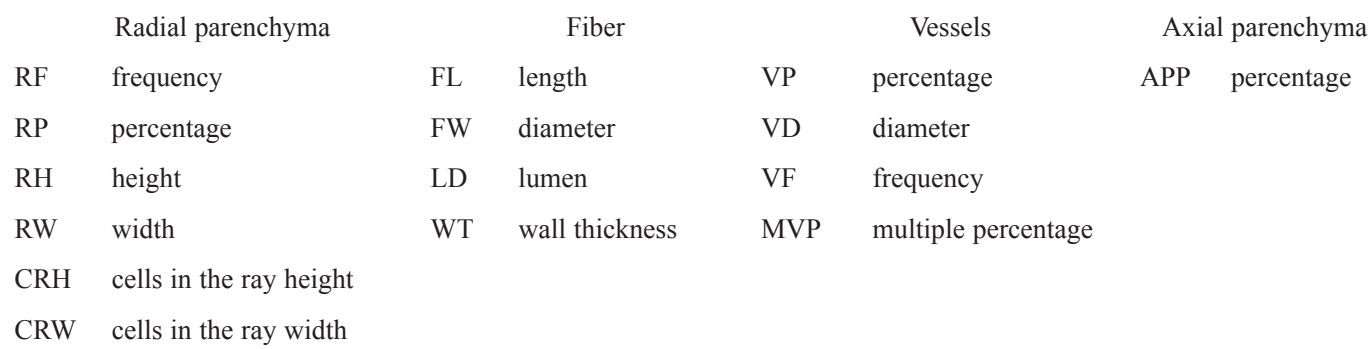

following microscopic terminology for hardwood identification (IAWA Committee 1989). The APP, RP and VP were calculated in transversal sections, then the area of these woody elements was measured and divided in the total area of digital image. The digital images of all anatomical features were processed with the Image Analysis System for wood (SAIM) developed for The Anatomy and Tree-ring Laboratory of São Paulo University, Brazil (Ribeiro 2002) an Image ToolC developed by "Health Science Center/ Texas University", EUA. Firstly, wood anatomical descriptions are noted considering as average all sampled trees and afterwards anatomical variation between dry and wet tropical climate is reported.

Statistic Analysis: the values of fiber dimensions (FL, FW, LD and WT) obtained per year and the values of vessels (VF, MVP), axial parenchyma (APP), and radial parenchyma (RF, $\mathrm{RP} \mathrm{RH}, \mathrm{RW}, \mathrm{CRH}$ and $\mathrm{CRH}$ ) measured in the four radial positions were averaged in only one value per tree. Afterwards, the normality and the presence of extreme data or outliers were verified for each anatomical character. Pearson matrix correlation was applied, in which were included all the anatomical characteristics and the different ecological conditions (altitude, length, latitude, and precipitation). Regression analysis and scatter plot for anatomical character with statistical coefficient in Pearson matrix were used to show the relationship of these variables.

Finally, we used canonical correlation multivariate analysis between the ecological variables and anatomical features, which is established as a linear combination of two sets of variables so the correlation between both is maximized (Johnson and Wichern 1992). The independent variables were the latitude, length, altitude and precipitation while the dependent variables were anatomical characters. Statistical SAS and STATISTICA program were used to evaluate the meaning of the regression model.

\section{RESULTS}

General features: wood with density of $0.51 \mathrm{~g} / \mathrm{cm}^{3}$ in air-dry conditions, heartwood differentiated in pale yellow color $(2.5 \mathrm{Y} 8 / 4)$ with pink color (7.5YR 7/4) lines and a white color sapwood (2.5Y 8/1.5). More distinct growth rings were found in melina trees grown on dry sites with precipitation presenting less than $2140 \mathrm{~mm} /$ year and less-distinct on humid sites with precipitation higher than $3100 \mathrm{~mm} /$ year. Vessels are distinct at $10 \mathrm{X}$. Axial parenchyma is non-distinct to the naked eye while ray parenchyma is lightly visible to simple eye.

Microscopic features: in general wood anatomy of $G$. arborea trees was similar in all samples. However some differences were found in fiber and vessels elements, which will be discussed later the following descriptions correspond to the average of two climatic conditions. The $G$. arborea wood from trees growing in wet tropical condition presents 
diffuse porosity while semi-ring or ring porosity is observed in trees growing in dry tropical condition. Vessels $4.5(3-6) / \mathrm{mm}^{2}$, solitary $85.19 \%(72.54-93.57 \%)$ and in multiple radial of 2-3 angular or oval in transverse section, average vessel member length $150 \mu \mathrm{m}$ (94-342 $\mu \mathrm{m})$; average tangential diameter 189 (85-240) $\mu \mathrm{m}$. Plate simple perforations, tyloses noted in heartwood vessels in all samples. Intervessels pits bordered, polygonal, alternate, tangential diameter $4.5(3.5-8.5) \mu \mathrm{m}$, nonvestured aperture. Vessel-ray pits similar to inter-vessels pits size and shape throughout the ray cell, average diameter $4.5 \mu \mathrm{m}$ (3.5-8.5 $\mu \mathrm{m})$. Fibers: with thin or very thin wall, 1-3 septo/fiber, simple to minutely bordered pits. Length $1.02 \mathrm{~mm}$ (0.94-1.59 mm); diameter $35.25 \mu \mathrm{m}(22.79-46.53 \mu \mathrm{m})$; lumen diameter $22.50(12.25-35.53 \mu \mathrm{m})$ and cell wall thickness $4.56 \mu \mathrm{m}(2.37-6.01 \mu \mathrm{m})$. Rays 1-5 (mostly 3-4) cells or mean $115 \mu \mathrm{m}(86-126 \mu \mathrm{m})$ in width, 14 (7-27) cells or $270 \mu \mathrm{m}(100-498 \mu \mathrm{m})$ in height, 5.6 (4-7) ray by $\mathrm{mm}$. Absent storied structure, heterocelular ray, body composed of procumbent cells with a row of upright and /or squared marginal cells, and crystals were not observed. Axial parenchyma is vasicentric and aliform and it is composed by 3 to 5 cells per strand.

Anatomy variation: in the present study, some anatomical characteristics were consistent in melina trees according to climatic variations conditions, especially in parenchyma ray. The altitude was the ecological parameter that less affected the wood anatomy (Table 3). Vessels, axial parenchyma, and fibers were affected significantly by the longitude, latitude, altitude and precipitation. The longitude only affected VP, and FD. The latitude significantly affected the VP, RP, FW, and LD. The altitude showed a statistic relationship with $\mathrm{CRH}$, while the annual average precipitation showed effects on VP, FW, and LD (Table 3).

The dependencies of the anatomical features to ecological conditions are shown in Figures 5, 6 and 7. The dependencies are expressed in regression equations as well as on percentages of the total variation explained by each ecological condition. As the latitude increases, the RP, FW, and LD decrease (Fig. $5 \mathrm{~A}, 5 \mathrm{~B}$ and 5D), but VP increases (Fig. 5C). As the longitude increases, LD increases (Fig. 6A) and VP decreases (Fig. 6B). As the altitude increases, $\mathrm{CRH}$ decreases. As the precipitation increases, VP decreases while $\mathrm{FW}$ and LD increase (Fig. 7A, 7B, 7C). There are no significant dependencies on ecological parameters for VP, VD, log (VF), MVP, RF, RW, RH, CRW, APP, FL, and WT (Table 3). The variation in wood structure, explained by the ecological conditions variation, was in general very low (Fig. 5, 6, 7). However, our analysis did not take into account the fact that plantation management condition, seed source, growth rate, plantation density, and breast diameter were different for each tree sampled.

Pearson matrix coefficients for anatomical features and ecological condition showed significant mutual correlations among anatomical features, mainly for vessel elements and others characters. High mutual correlation was found for VP and RH; VP and FW; VD and VF, VD and RF; VF and FW; VF and LD; RP and RW; $\mathrm{RP}$ and $\mathrm{CRW}$; RW and CRW; RH and RCH. Plantation conditions, mainly for diameter breast height (DBH) significant correlations with anatomical features were also found. There were high correlation with VD, VF, RP, RW, CRW, FL, FW and LD (Table 3). On the other hand, we established that only VP, RP, CRH, FW and LD were statistically significant with ecological parameters. Then, although RH, VD, VF, RF, $\mathrm{RP}, \mathrm{RW}$, and RCH lack of significant correlations with ecological conductions, Pearson coefficients showed their dependence with others anatomical characters correlated with latitude, longitude, altitude and precipitation.

Multivariate analysis by canonical correlation: the analysis of multivariate canonical correlation showed that the variations of the anatomical elements of melina trees growing in Costa Rica can be explained (up to 91\%) by the ecological parameters (latitude, longitude, altitude, and precipitation). The model of canonical correlation between the ecological 


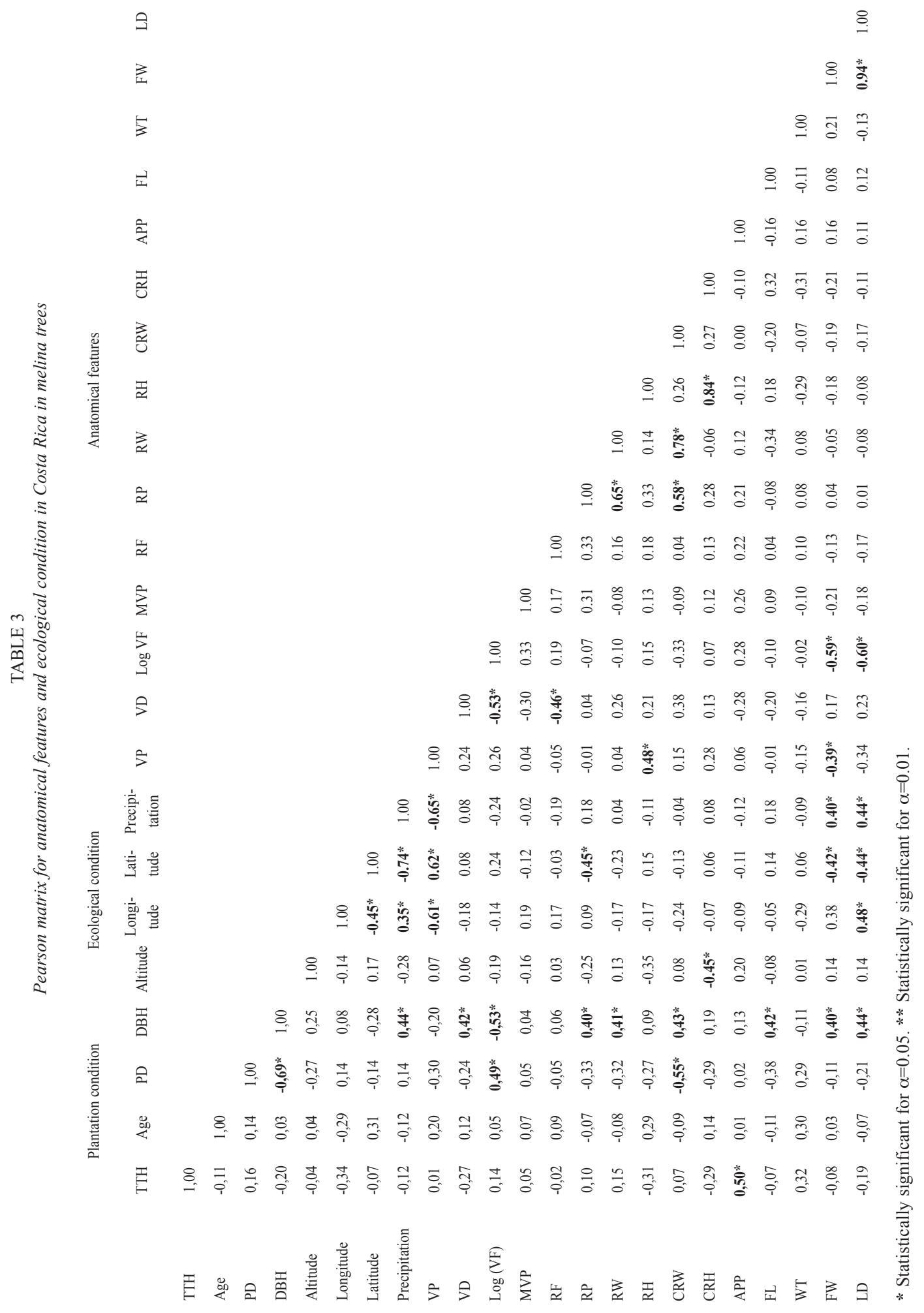



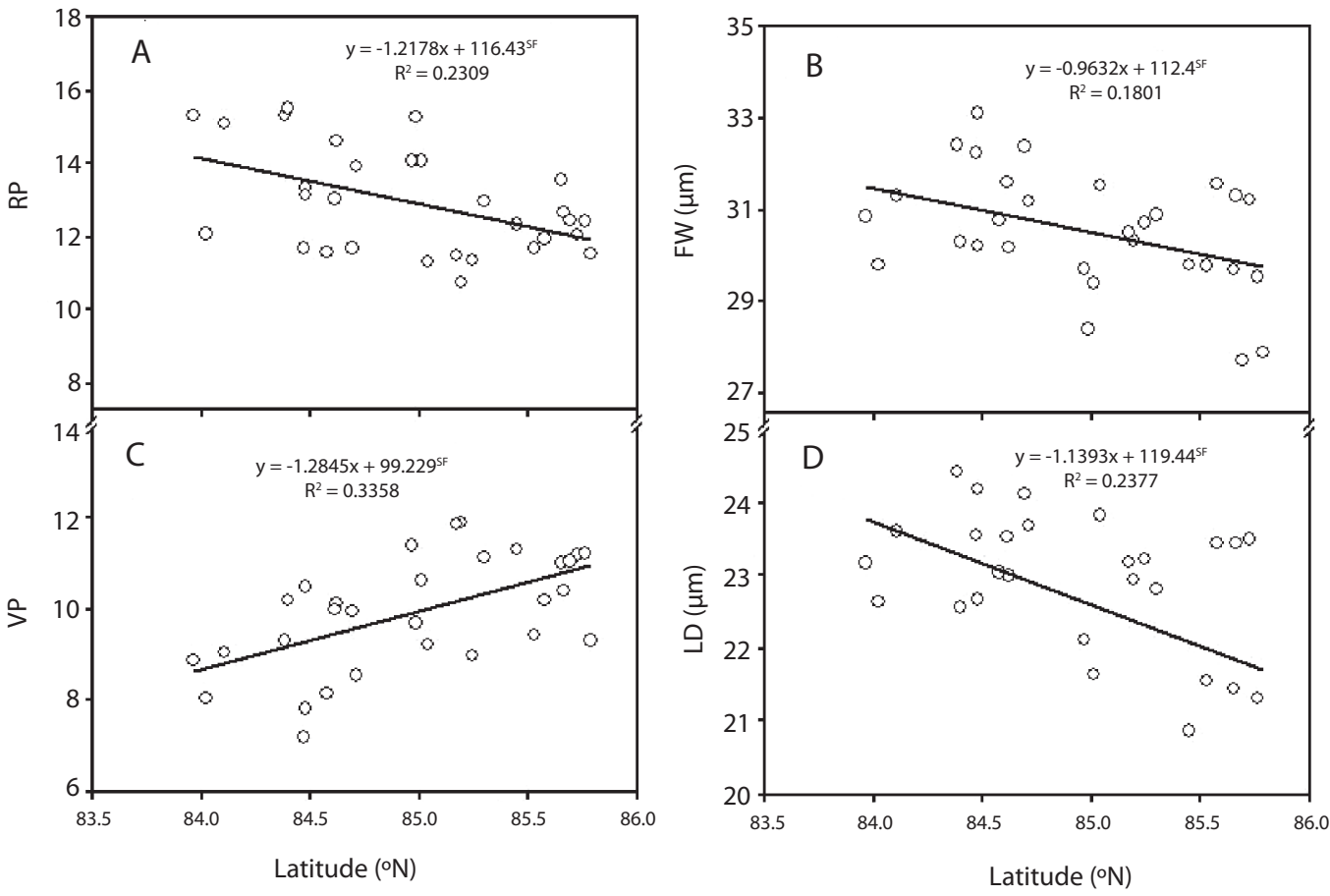

Fig. 5. Relationships between several anatomical features and latitude for Gmelina arborea in Costa Rica (Note: SF: statistically significant for $\alpha=0.01)$.
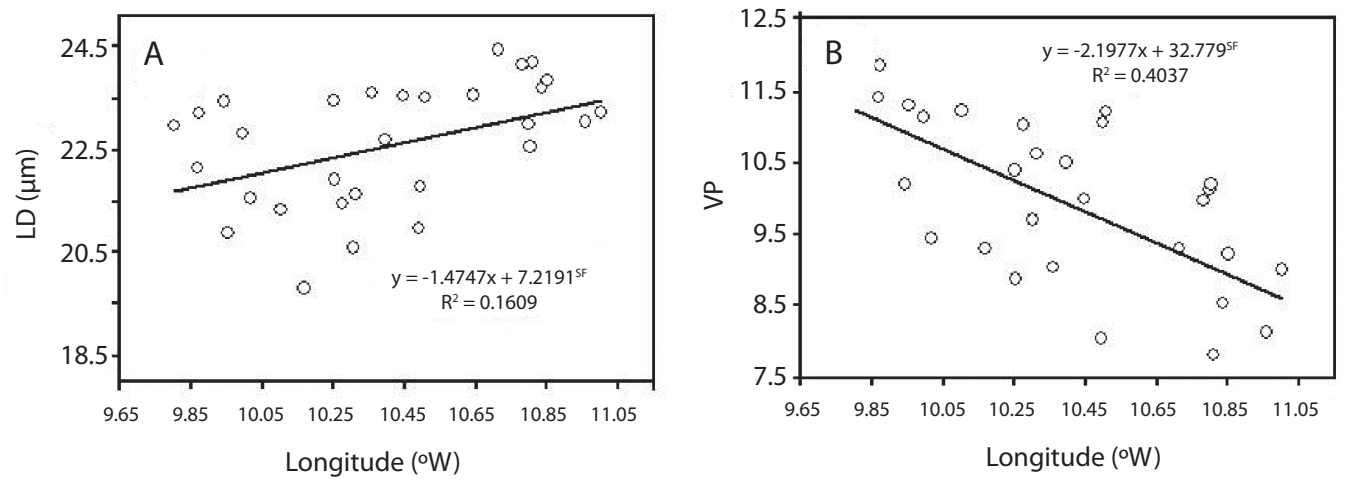

Fig. 6. Relationships between lumen diameter and vessels percentage with and longitude for Gmelina arborea in Costa Rica. (Note: SF: statistically significant for $\alpha=0.01$ ). 

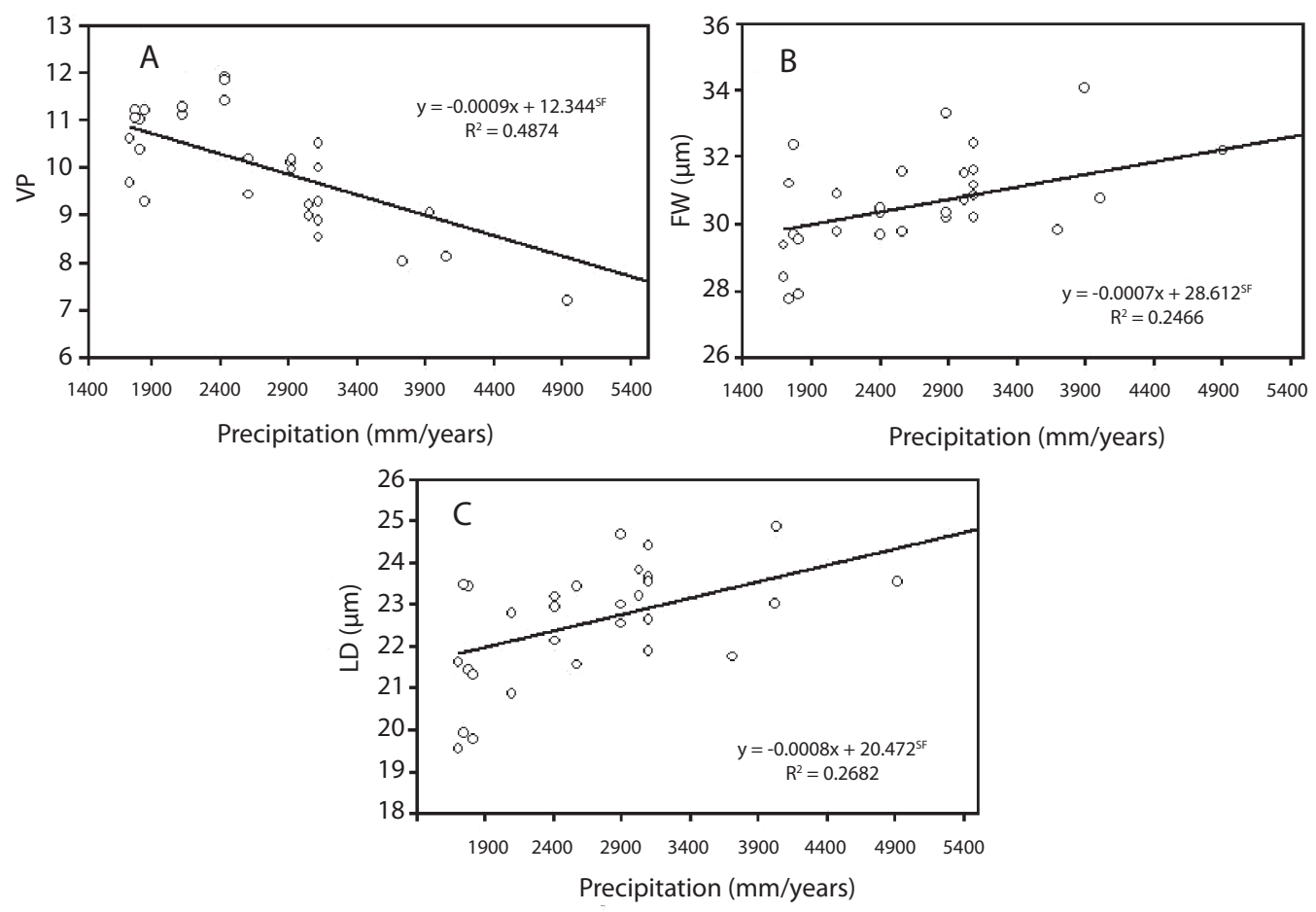

Fig. 7. Relationships between VP, FW and LD with precipitation for Gmelina arborea in Costa Rica. (Note: SF: statistically significant for $\alpha=0.01)$.

parameters (latitude, longitude, altitude, and precipitation) and anatomical features established two canonical components with high degree of explanation. The first component explained the $78.5 \%$ of the variability and the second one a $12.2 \%$ (Table 4). According to these results, the greatest variation of the wood anatomy by the ecological conditions occurred in main component 1 . Figure 8 shows canonical loadings of ecological parameters and anatomical features of secondary xylem in canonical component 1 . There was a strong correlation between loadings of ecological parameters and loadings of the anatomical features $\left(\mathrm{R}^{2}=0.87\right)$, and it is possible to observe that sampled trees from wet tropical conditions are separated from sampled trees from dry tropical conditions. On the other hand, the

TABLE 4

Statistical parameters of canonical correlation between ecological conditions and anatomical features in Gmelina arborea trees growing in Costa Rica $(N=30)$

$\begin{array}{ccccc}\begin{array}{c}\text { Canonical } \\ \text { components }\end{array} & \begin{array}{c}\text { Canonical } \\ \text { Correlation }\end{array} & \text { Auto-vector } & \text { Percentage of variance } & \text { Accumulate variance } \\ 1 & 0.966 & 14.198 & 0.785 & 0.785 \\ 2 & 0.830 & 2.211 & 0.122 & 0.907 \\ 3 & 0.736 & 1.182 & 0.065 & 0.973 \\ 4 & 0.571 & 0.485 & 0.027 & 1.000\end{array}$




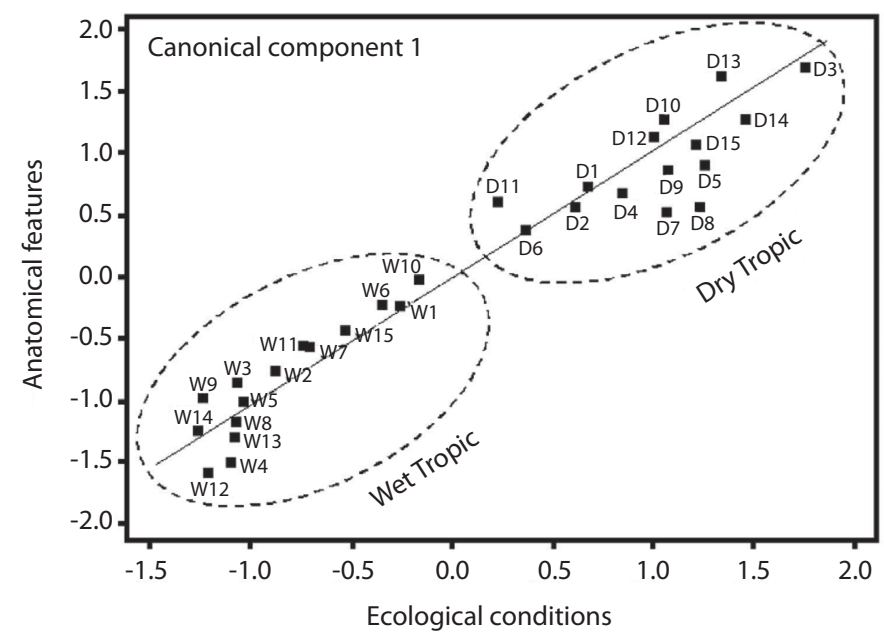

Fig. 8. Canonical relationship between ecological conditions and anatomical features in canonical component 1.

ecological parameters and VD, FW and LD were correlated with canonical component 1 while VD, RP, CRH, APP, FL, altitude and precipitation presented correlation with canonical component 2 (Table 5).

\section{DISCUSSION}

Some anatomical characteristics of secondary xylem differ from the description made by Pearson and Brown (1932) for melina trees growing in India. The growth ring is the most remarkable difference. Pearson and Brown (1932) mentioned wood with annular porosity or semi-annular porosity; however, our studies showed that this characteristic is only present in all sites with annual precipitations inferior to $3500 \mathrm{~mm} /$ year. Other difference in relation to the wood grown in India is apotraqueal parenchyma diffuse, which was not observed in the samples from Costa Rica. The apotraqueal parenchyma difference between Pearson and Brown's description (1932) and our results can be attributed to wide fiber diameter which can be confused with parenchyma. Frequency of vessels and rays and number of cells of radial parenchyma were different between trees from Costa Rica and India too. They were larger than those found in melina trees growing in
Costa Rica. On the other hand, the description presented by the project "Inside Wood" (Wheeler et al. 2006) and "www.delta-intkey. com" (Richter and Dallwitz 2002) shows some similarities in the anatomy of the samples from Costa Rica, such as the distinct and indistinct growth ring, tyloses and crystals presence, fiber dimensions, type, and distribution of the vessels and axial parenchyma.

Although Costa Rica presents little variation in latitude and longitude (approximately $2^{\circ}$ in each one of the coordinates), it was evident the relation between some anatomical parameters, indicating an adaptation of woody tissue to the different ecological conditions. In addition, the obtained results for the trees growing in Costa Rica were similar to other studies made in other regions of Asia or Africa (Chowdhury 1947, 1953, Akachuku and Burley 1979, Akachuku 1985, Ohtani et al. 1989), which demonstrated that the vessels and parenchyma are the main elements of secondary xylem that reflect ecological variations. However, Akachuku and Burley (1979) had demonstrated that G. arborea wood structure was not affected by latitude or longitude for trees growing in Nigeria with great latitude and longitude variation.

Lindorf (1994), studying several species of the dry tropical regions of Venezuela, found 
TABLE 5

Correlations between the variables and their canonical variables in Gmelina arborea trees growing in Costa Rica $(N=30)$

\begin{tabular}{|c|c|c|c|c|}
\hline Variables & $\begin{array}{c}\text { Canonical } \\
\text { component } 1\end{array}$ & $\begin{array}{c}\text { Canonical } \\
\text { component } 3\end{array}$ & $\begin{array}{c}\text { Canonical } \\
\text { component } 4\end{array}$ & $\begin{array}{c}\text { Canonical } \\
\text { component } 5\end{array}$ \\
\hline VP & 0,578 & 0,167 & $-0,352$ & $-0,266$ \\
\hline VD & 0,135 & 0,344 & $-0,013$ & $-0,502$ \\
\hline $\log (\mathrm{VF})$ & 0,224 & $-0,103$ & $-0,149$ & 0,232 \\
\hline MVP & $-0,201$ & $-0,194$ & $-0,060$ & 0,126 \\
\hline RF & $-0,176$ & $-0,293$ & $-0,295$ & $-0,007$ \\
\hline $\mathrm{RP}$ & $-0,275$ & $-0,352$ & 0,327 & $-0,447$ \\
\hline RW & 0,016 & $-0,305$ & 0,288 & $-0,489$ \\
\hline RH & 0,132 & 0,185 & $-0,259$ & $-0,598$ \\
\hline CRW & 0,095 & $-0,245$ & 0,172 & $-0,600$ \\
\hline $\mathrm{CRH}$ & 0,047 & 0,331 & $-0,085$ & $-0,383$ \\
\hline APP & 0,067 & $-0,551$ & 0,273 & 0,325 \\
\hline FL & 0,128 & 0,469 & 0,127 & 0,274 \\
\hline WT & 0,275 & $-0,225$ & 0,246 & 0,054 \\
\hline FW & $-0,445$ & 0,104 & 0,280 & 0,066 \\
\hline LD & $-0,545$ & 0,181 & 0,202 & 0,051 \\
\hline Altitude & 0.331 & -0.526 & 0.383 & 0,217 \\
\hline Latitude & -0.891 & 0.089 & -0.144 & 0.181 \\
\hline Longitude & 0.699 & 0.136 & -0.461 & 0.137 \\
\hline Precipitation & -0.476 & 0.401 & 0.532 & -0.027 \\
\hline
\end{tabular}

similar results to those obtained for melina in Costa Rica. He found that numerous vessels, small diameter, short vessels elements and minute intervessels pits were observed in species of dry forest. He mentioned that the modifications in the parameters of the vessels, radial parenchyma, and axial parenchyma can be interpreted as a strategy for conductive safety variability when the water stress is present. Several researches have found alterations in the anatomy due to the variation of the geographic position (latitude and longitude) and the altitude for others species. For example, the VP, VD, VF, and MVP parameters of Dodonaea viscosa (Liu and Noshiro 2003), Cornus controversa, C. macrophyla (Noshiro and Baas 2000), some Symplocos family members (Van der Oever et al. 1981) and Ilex sp (Baas 1973), and a few species of Vaccinioideae and Vaccinium families (Lens et al. 2004) showed a relation with the latitude. These results differed from ours since only VP was statistically significant with the latitude, longitude and altitude. VP measures indirectly water conductivity into trunk (Villar et al. 1994) and this capacity is correlated with precipitation, which is significantly correlated with latitude and longitude in Costa Rica region (Table 3). The little variation of latitude and longitude in Costa Rica can be one of the causes by which it is not possible to detect effects of these ecological parameters on the other parameters of the vessels, as it happened in the previous studies, where trees were sampled in latitude greater amplitude.

The FL in D. viscosa and C. macrophyla (Noshiro and Baas 2000, Liu and Noshiro 
2003) did not show relation with the latitude like FL of melina found in this research. These results differed from the ones found for $C$. controversa, C. kousa, Vaccinioideae, Vaccinium and Symplocos families that were negatively correlated with latitude (Lens et al. 2004, Van der Oever et al. 1981). Radial parenchyma is one of the less studied parameters. However, for Vaccinioideae and Vaccinium (Lens et al. 2004) a correlation with the altitude and length was found and similar results were found for the melina trees from Costa Rica. However, the RH showed negative correlation with the latitude for Vaccinioideae and Vaccinium (Lens et al. 2004), but it was not influenced for latitude in melina (Table 3).

Some other investigations with other species and in other latitudes have shown the effect of precipitation on the anatomical characters. For instance, for trees of Quercus coccifera, Q. ilex, and Q. faginea in Spain (Villar 1997), it was found a statistically significant correlation between this ecological condition with the density and the diameter of pores of these three species. Similar results were obtained for melina in the different precipitation levels in Costa Rica. On the other hand, for 115 species of Vaccinioideae family (Lens et al. 2004) it was found that the precipitation affected significantly the VD, vessel length, VF, and RW. The results of the present study differed from those of the Vaccinioideae family because these anatomical parameters were not affected by precipitation. Significant influence of plantation condition may probably affect those anatomical features because VD, VF and RW were influenced significantly by DBH (Table 3$)$.

Wiemann and Willianson (2002) established, after an intense bibliographical revision, that the anatomical characteristics of the trees are determined by the ecological conditions of the sites in which they are grown, especially in aspects related to water availability due to their narrow correlation with water conduction tissue within the tree (Van der Oever et al. 1981, Taiz and Zeiger 2004). Water availability for precipitation affects the physiological process- es of the tree (Yang et al. 2003). Nevertheless, for the results obtained for melina trees, the precipitation levels did not reflect effects in these elements (vessels and ray parenchyma) of the trees. However, VP for vessels element and two parameters of fibers (FW and LD) only showed a significant statistical relation with the annual average precipitation of the studied sites (Fig. 7B, 7C). Fast-growth conditions of trees in plantation probably present greater influence on xylem structure than ecological condition, DBH affected quantitative wood structure in a considerable way, that is to say, VD, VF, RP, RW, CRW, FL, FW and LD (Table 3).

VP, RP, FL, FW, CRW and LD presented some relationship with some ecological parameters (Table 3, Fig. 4-7). Multivariate analyses confirmed also the variation of VP, RP, FL, FW and LD for ecological conditions, but for CRW was no found any relation in this analysis. Those features were highly correlated with two canonical components (Table 5). Two canonical components obtained from multivariate analyses can be interpreted with the variation of wood structure for conductive water into the trunk for variation the ecological conditions. Anatomical features, VP, VD, RP and fibers dimensions (FL, FW and LD) and ecological conditions (altitude, longitude, latitude and precipitation) were correlated with two canonical components (Table 5). Those anatomical features are important parameters for two vital functions carried out by xylem in living trees, which varied with growing conditions of trees. The resistance to flow is proportional to the fourth power of the vessels radius and to vessels frequency (Zimmermann 1971). The mechanical resistance depends on fiber dimensions (Van der Oever et al. 1981, Domec and Gartner 2002).

Although other anatomical characters were not correlated with ecological conditions, Pearson correlation coefficient showed that some anatomical features were strongly correlated among them. It means that, changes in one or two of the features would bring changes in other features. The direct or indirect effects of ecological conditions for $G$. arborea are 
indicators of xylem adaptation to different ecological conditions present in Costa Rica.

\section{RESUMEN}

Gmelina arborea ha sido introducida y ampliamente sembrada en Costa Rica en plantaciones de rápido crecimiento. Estas nuevas condiciones ecológicas provocan variación en la anatomía del xilema de estos árboles. El presente trabajo tuvo como objetivo determinar la variación en la anatomía del xilema debido a la variación de la latitud, longitud, altitud y precipitación. Se evaluaron las dimensiones de las fibras, el porcentaje de área ocupada por el parénquima y los parámetros de los vasos y los radios. Algunas características anatómicas se mantuvieron estables con las variaciones de las condiciones ecológicas evaluadas, especialmente el parénquima radial. La altitud es la condición ecológica con menor afecto en la anatomía de la madera. Los vasos, el parénquima axial y las fibras fueron menos estables debido a que fueron afectados significativamente por la longitud, latitud, altitud y precipitación. La latitud afectó significativamente el porcentaje de vasos, porcentaje de radios, largo y diámetro de la fibra y diámetro del lumen; la longitud afectó el porcentaje de vasos y el diámetro de la fibra; la altitud únicamente mostró relación significativa con la cantidad de células en la altura de los radios. La precipitación media anual mostró efectos sobre el porcentaje de poros y el diámetro de la fibra y el lumen. Dichos resultados sugieren que las condiciones de crecimiento en Costa Rica para G. arborea son indicadores de un posible genotipo del árbol.

Palabras clave: Madera de plantación, propiedades, xilema secundario, posición geográfica, precipitación.

\section{REFERENCES}

Akachuku, A.E. 1985. The effects of some extrinsic and intrinsic factors on the proportion of vessels in Gmelina arborea Roxb. Wood Sci. Tech. 19: 5-12.

Akachuku, A.E. \& J. Burley. 1979. Variation of anatomy of Gmelina arborea Roxb. in Nigerian plantations. IAWA Bull 4: 94-99.

Alfaro, M. 2000. Melina: la madera del futuro. Rev. For. Centroamericana 29: 34-38.

Alfaro, M. \& R. De Camino. 2002. Melina (Gmelina arborea) in Central America. Working Paper 20. FAO, Forest Resources Division, Forest Resources Development Service, Rome, Italy.

Baas, P. 1982. Systematic, phylogenetic and ecological wood anatomy, p. 23-58. In P. Baas (ed.). New perspectives in wood anatomy: systematic, phylogenetic and ecological wood anatomy. Martinus Nijhoff Publishers. The Hague, The Netherlands.

Baas, P. 1973. The wood anatomical range in Ilex (Aquifoliaceae) and its ecological and phylogenetic significance. Blumea 21: 193-258.

Baas, P., E. Werker \& A. Fahan. 2004. Some ecological trends in vessel characters. IAWA J. 4: 141-160.

Bolaños, R. \& V. Watson. 1993. Mapa ecológico de Costa Rica. Según el sistema de clasificación de zonas de vida del mundo de L.R. Holdridge. Escala 1: 200000. Centro Científico Tropical, San José, Costa Rica.

Chowdhury, K.A. 1947. Initial parenchyma cells in dicotyledonous. Nature 160: 609.

Chowdhury, K.A. 1953. The role of initial parenchyma in the transformation of the structure diffuseporous to ring-porous in the secondary xylem of the genus Gmelina Linn. Proc. Nat. Inst. Sci. India 19: 361-369.

Domec, J.C. \& B.L. Gartner. 2002. Age- and positionrelated changes in hydraulic versus mechanical dysfunction of xylem: inferring the design criteria for Douglas-fir wood structure. Tree Phy. 22: 91-104.

Douay, J. 1956. Bois d'allumetes a la recherche d'essences noulles. Rev. Bois For. Trop. 52: 43-48.

Dvorak, W.S. 2004. World view of Gmelina arborea: opportunities and challenges. New For. 28: 111-126.

Esan, R.F. 1966. Study of variation in some structural features and properties of Gmelina arborea Roxb. Ph.D. Thesis, Faculty of Forestry, University of Oxford, Oxfort, England.

Frimpong-Mensah, K. 1992. Wood quality variation in the tree of some endemic tropical species, p. 25-26. In Association pour la Reserche sur le bois en Larraine \& International Union of Forestry Research Organizations (eds.). Working Sessions Vol. 1. All Division 5 Conference "Forest Products", Nancy, France.

Hornick, J.R., J.I. Zerbe \& J.L Whitmore. 1984. Jari`s successes. J. For. 82: 663-667.

Hughes, J.F. \& D. Esan. 1969. Variation in some structural features and properties of Gmelina arborea. Trop. Sci. 1: 23-37.

IAWA Committee. 1989. List of microscopic features for hardwood identification. IAWA Bull. 10: 226-332. 
Johnson, R.A. \& D.W. Wichern. 1992. Applied multivariate statistical analysis. MacGraw-Hill, New York, USA.

Kalish, J. 1975. The Jari: Project in Northern Brazil. Pulp Paper Int. 21: 37-52.

Lamb, A.F.A. 1968. Fast growing timber trees of the lowland tropics No. 1: Gmelina arborea. University of Oxford and Commonwealth Forestry Institute, Oxford, England.

Lens, F., J.L. Luteyn, E. Smets \& S. Jasen. 2004. Ecological trends in the wood anatomy of Vaccinioideae (Ericaceae s.1.). Flora 199: 309-319.

Lindorf, H. 1994. Eco-anatomical wood features of species from a very dry tropical forest. IAWA J. 15: 361-376.

Liu, J. \& S. Noshiro. 2003. Lack of latitudinal trends in wood anatomy of Dodonaea viscosa (Sapindaceae). Am. J. Bot. 90: 532-539.

Mac Corporation. 1994. Munsell soil color charts. Kollmorgen Instruments Corporation, New York, USA.

Metcalfe, C.R. 1989. Ecological anatomy and morphology general survey, p.126-152. In C.R. Metcalfe \& L. Chalk (eds.). Anatomy of the dicotyledons. Wood structural and conclusion of the general introduction. Oxford Science, Oxford, England.

Moya, R. 2004. Wood of Gmelina arborea in Costa Rica. New For. 28: 299-307.

Moya, R.\& M. Tomazello. 2007. Relationship between anatomical features and intra-ring wood density profiles in Gmelina arborea applying X-ray densitometry. Cerne 13(4): 384-392.

Nobuchi, T., C. Kami \& M. Fujita. 1997. Radial variation of vessel and fiber dimensions in some plantation grown tropical trees as it relates to wood qualities, p. 81-101. In International Tropical Wood "New Tropical Timber Crops: Challenges in Processing and Utilization". , Faculty of Forestry, Universiti Putra Malaysia, Kuala Lumpar, Malaysia.

Noshiro, S. \& P. Baas. 2000. Latitudinal trends in wood anatomy within species and genera: case in Cornus S.L. (Cornaceae). Am. J. Bot. 87: 1495-1506.
Ogbonnaya, C.I. 1993. Effects of nitrogen sources on the wood properties of Gmelina arborea relevant to pulp and paper production. For. Ecol. Manag. 56: 211-223.

Ogbonnaya, C.I., M.C. Nwalozie \& L.C. Nwaigro. 1992. Growth and wood properties of Gmelina arborea (Verbenaceae) seedlings grown under five soil moisture regimes. Am. J. Bot. 79: 128-132.

Ohbayashi, H. \& T. Shiokura. 1989. Anatomical structure of fast-growing tropical tree species with differing growth rates. IAWA Bull. 10: 342-343.

Ohtani, J., W. Jing, K. Fukazawa \& X. Shao Qun. 1989. Multiple perforation plates in Gmelina arborea Roxb. (Verbenaceae). IAWA Bull. 10: 35-41.

Pearson, R.S. \& H.P. Brown. 1932. Commercial timber of India. Government of India Central Publication Branch, New Delhi, India.

Plomion, C., G. Leprovost \& A. Stokes. 2001. Wood Formation in Trees. Physiology 127: 1513-1523.

Ribeiro, T.P. 2002. Método de complementar de análise da qualidade da madeira com técnicas de processamento digital de imagens. M. Sc. Thesis, Universidade Federal de São Calos, São Carlos, Brazil.

Ruzin, S.E. 1999. Plant Microtechnique and Microscopy. Oxford University, New York, USA.

Taiz, L. \& E. Zeiger. 2004. Fisiologia vegetal. Trad. E. Romanato, Artmed, Porto Alegre, Brazil.

Van Der Oever, L., P. Baas, P. \& M. Zandee. 1981. Comparative wood anatomy of Symplocos and latitude and altitude of provenance. IAWA Bull. n.s. 2:3-24.

Villar, P., P. Castro, P. Pérez \& G. Montserrat-Martí. 1997. Stem xylem features in three Quercus (Fagaceae) species along a climatic gradient in NE Spain. Trees 12: 90-96.

Walter, H. \& H. Lieth. 1960. Klimadiagramm. Wetatlas. VEB Gustaf Fischer, Berlin, Germany.

Wiemann, M. \& G.B. Willianson. 2002. Geographic variation in wood specific gravity: effects of latitude, temperature and precipitation. Wood Fiber Sci. 34: 96-107. 
Yang, J., S. Park, D.P. Kamdem, D.E. Keathley, E. Retzel, C. Paule, V. Kapur \& K. Han. 2003. Novel gene expression profiles define the metabolic and physiological processes characteristic of wood and its extractive formation in a hardwood tree species, Robinia pseudoacacia. Plant Mol. Biol. 52: 935-956.

Zimmermann, M. 1971. Transport in the xylem, p.156-178. In M. Zimmermann \& C.L. Brown (eds.). Trees structure and function. Springer, New York, USA.

Zobel, B. \& B. Van Buijtenen. 1989. Wood variation: its causes and control. Springer, New York, USA.

\section{INTERNET REFERENCE}

Richter, H.G. \& M.J. Dallwitz. 2000. Commercial timbers: descriptions, illustrations, identification, and information retrieval. In English, French, German, Portuguese, and Spanish. (Downloaded: April 16th, 2006; http://delta-intkey.com).

Wheeler, E.A., T.D. Simpson, S.L. Rogers, P.E. Gasson, K.R. Brown, J.R. Barlett \& R. Baas. 2006. Inside Wood: A new internet-accessible wood anatomy database. (Downloaded: July 03rd, 2006; http:// insidewood.lib.ncsu.edu/search/) 